JAMP: Jurnal Adminitrasi dan Manajemen Pendidikan

Volume 3 Nomor 3 September 2020, Hal : 262-271

Tersedia Online di http://journal2.um.ac.id/index.php/jamp/

ISSN 2615-8574 (online)

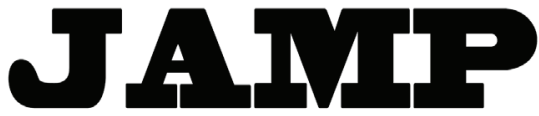

JURNAL ADMINISTRASI DAN MANAJEMEN PENDIDIKAN

\title{
VALIDITAS DAN RELIABELITAS ANGKET GAYA KEPEMIMPINAN MAHASISWA
}

\author{
Djum Djum Noor Benty ${ }^{1}$ \\ Imam Gunawan ${ }^{2}$ \\ Desi Eri Kusumaningrum ${ }^{3}$ \\ Raden Bambang Sumarsono ${ }^{4}$ \\ Dika Novita Sari ${ }^{5}$ \\ Firda Dwi Pratiwi ${ }^{6}$ \\ Sari Oktavia Ningsih ${ }^{7}$ \\ Lim Kim Hui ${ }^{8}$
}

\author{
1,2,3,4,5,6,7 Universitas Negeri Malang, Jalan Semarang 5 Malang 65145 \\ ${ }^{8}$ Hankuk University of Foreign Studies, Seoul, South Korea \\ Email: djum.djum.fip@um.ac.id
}

\begin{abstract}
The instrument has a crucial function in a research. The accuracy of the data taken is also influenced by the validity of the research instrument. The validity of the research instrument will also affect the accuracy of research conclusions. Therefore, before using an instrument to retrieve data, its validity and reliability must be tested. This study tested the validity and reliability of the questionnaire instrument of the student leadership style variables. The indicators used to compile the questionnaire statement items for the student leadership style variables based on the theory of Yukl (2015), Usman (2013), and Gunawan (2018), namely: autocratic; bureaucratic; diplomatic; participative; and free rein leader. Based on this theory, 10 items were developed to measure the student leadership style variables. The research sample was 35 students of UKM KSR PMI Unit Universitas Negeri Malang (student organizations engaged in the red cross). The formula used to test the validity is the Pearson Product Moment Correlation formula, while the formula used to test the reliability is the Cronbach's Alpha formula. The results of the validity analysis concluded that all statement items developed ( 10 items) had a probability value $(\alpha)<0.05$; so it can be concluded that the instrument is valid for measuring the variable student leadership style. The results of the reliability analysis showed that the value of $r_{\text {alpha }}=0.799>r_{\text {table }}=0.468$; so it can be concluded that the instrument is reliable for measuring the variable student leadership style.
\end{abstract}

Keywords: validity, reliability, student leadership style, autocratic, bureaucratic, diplomatic, participative, free rein leader

Abstrak: Instrumen memiliki fungsi yang krusial dalam suatu penelitian. Ketepatan data yang diambil juga dipengaruhi oleh tingkat kevalidan instrumen penelitian. Kevalidan instrumen penelitian juga akan mempengaruhi ketepatan simpulan penelitian. Oleh sebab itu, suatu instrumen sebelum digunakan untuk mengambil data, harus diuji validitas dan reliabelitasnya. Penelitian ini menguji validitas dan reliabelitas instrumen angket variabel gaya kepemimpinan mahasiswa. Jabaran indikator yang digunakan untuk menyusun item pernyataan angket variabel gaya kepemimpinan mahasiswa berdasarkan teori Yukl (2015), Usman (2013), dan Gunawan (2018), yaitu: autokratis; birokratik; diplomatis; partisipatif; dan free rein leader. Berdasarkan teori tersebut, ada 10 item yang dikembangkan untuk mengukur variabel gaya kepemimpinan mahasiswa. Sampel penelitian adalah 35 mahasiswa UKM KSR PMI Unit Universitas Negeri Malang. Rumus yang digunakan untuk menguji validitas adalah dengan rumus Korelasi Product Moment Pearson, sedangkan rumus yang digunakan untuk menguji reliabelitas adalah dengan rumus rumus Cronbach's Alpha. Hasil 
analisis validitas menyimpulkan semua item pernyataan yang dikembangkan (10 item) memiliki nilai probabilitas $(\alpha)<0,05$; sehingga dapat disimpulkan instrumen tersebut valid untuk mengukur variabel gaya kepemimpinan mahasiswa. Hasil analisis reliabelitas diperoleh nilai $r_{\text {alpha }}=0,799>r_{\text {tabel }}=0,468$; sehingga dapat disimpulkan instrumen tersebut reliabel untuk mengukur variabel gaya kepemimpinan mahasiswa.

Kata kunci: validitas, reliabelitas, gaya kepemimpinan mahasiswa, autokratis, birokratik, diplomatis, partisipatif, free rein leader

Kepemimpinan merupakan suatu topik yang tidak akan pernah usang dan akan selalu menarik untuk dikupas. Sudah banyak riset yang membuktikan bahwa kepemimpinan merupakan faktor yang menentukan dalam menjalankan roda organisasi. Keberhasilan organisasi dalam mencapai visi, misi, dan tujuan yang dituangkan dalam program kerja dipengaruhi oleh kepemimpinan yang dijalankan oleh orang yang ada dalam organisasi tersebut. Kepemimpinan memang lazim melekat pada diri seorang pemimpin organisasi, namun tidak menutup kemungkinan, insan yang bukan pemimpin organsiasi pun dapat memiliki karakter dan gaya kepemimpinan yang kuat dan baik. Kepemimpinan adalah kemampuan yang dimiliki oleh seseorang yang mampu mempengaruhi orang lain, sehingga orang tersebut ikut bergerak sesuai dengan dengan perilaku yang diharapkan.

Kepemimpinan secara teoritik bergerak secara kontium dari teori sifat, teori perilaku, sampai pada teori kontingensi (Gunawan, 2018). Setiap organisasi memiliki corak kepemimpinan masingmasing dengan berbagai keunikan sifat kepemimpinan yang dimiliki oleh organisasi tersebut. Seorang pemimpin tentu memiliki gaya kepemimpinan masing-masing yang dipengaruhi berbagai faktor, seperti sifat organisasi, kepribadian pemimpin itu sendiri, dan juga sifat bawahan yang ia pimpin. Kepemimpinan yang efektif menurut teori kepemimpinan kontingensi adalah pemimpin yang mampu memahami karakteristik bawahan dan situasi yang berkembang (Gunawan, 2018; Sudharta, dkk., 2017; Gunawan, 2017; Pertiwi, dkk., 2018). Berbagai penelitian pun telah dilakukan untuk mengukur tingkat kepemimpinan seseorang. Atas dasar rasional tersebut, penelitian ini melakukan uji validitas dan reliabelitas yang digunakan untuk mengukur variabel gaya kepemimpinan mahasiswa.

Mahasiswa sebagai generasi muda dan merupakan investasi kepemimpinan masa depan, sudah sepatutnya memiliki karakter kepemimpinan yang kuat. Mahasiswa merupakan generasi yang akan meneruskan estafet kepemimpinan di berbagai sektor yang ada dalam kehidupan bangsa Indonesia ini. Pada pundaknyalah ada tanggung jawab dan sekaligus juga tantangan, sebab kemajuan bangsa ditentukan oleh perilaku, sikap, kompetensi, dan juga karakter mahasiswa yang dimiliki bangsa ini. Mahasiswa saat ini, pada periode mendatang, akan mengisi roda pembangunan. Oleh sebab itu, sudah sepatutnya perguruan tinggi berupaya memberikan bekal ilmu pengetahuan, keterampilan, dan pengalaman dalam mengisi roda pembangunan pada masa mendatang.

Beberapa faktor yang mempengaruhi pengembangan kompetensi kepemimpinan mahasiswa adalah: (1) faktor individu meliputi kecerdasan emosional, efikasi diri, kepercayaan diri, dan ekstroversi; (2) pengalaman dan keterlibatan mahasiswa yang meliputi keterlibatan akademik, hubungan mahasiswafakultas, hubungan teman sebaya, posisi kepemimpinan di kelas dan organisasi kemahasiswaan; dan (3) lingkungan perguruan tinggi (Mozhgan, dkk., 2011; Gunawan, dkk., 2020; Gunawan, dkk., 2019). Karakter pemimpin mahasiswa yang berlandaskan pada nilia-nilai Pancasila menjadi faktor yang sangat diperlukan oleh bangsa Indonesia (Argadinata \& Gunawan, 2019; Bafadal, dkk., 2019; Sobri, dkk., 2019). Peran dosen dan pimpinan perguruan tinggi sangatlah diperlukan untuk mewujudkan mahasiswa yang memiliki jiwa kepemimpinan Pancasila. Kepemimpinan tersebut akan mewarnai corak gaya kepemimpinan mahasiswa (Sultoni, dkk., 2018a; Sultoni, dkk., 2018b; Sultoni, dkk., 2018c).

Kepemimpinan di era superkompleksitas seperti pada era sekarang harus diperhatikan. Milenium ketiga saat ini dengan ciri khasnya seperti hyper-change, hyper-industries, era komunikasi, dan era teknologi informasi serta dunia digital, membutuhkan pemimpin yang mampu maju, seiring dengan perubahan dunia. Pembinaan kepemimpinan mahasiswa dianggap sebagai matakuliah vital masa kini, karena pembinaan para pemimpin politik, sosial, ekonomi, budaya, ilmu pengetahuan dan teknologi 
(iptek), yang dapat mengambil kendali masyarakat dan memajukan dunia, dilakukan dalam sistem pendidikan perguruan tinggi. Teori pengembangan kepemimpinan mahasiswa dengan sikap komprehensif dan pandangan sistematis telah mempertimbangkan faktor-faktor yang mempengaruhi perkembangan kepemimpinan mahasiswa, baik dari aspek individu, kelompok maupun sosial (Amirianzadeh, 2012).

Melalui analisis data longitudinal, Hine (2014) mengemukakan karakteristik utama dari tujuh model kepemimpinan yang disajikan dalam literatur (kepemimpinan transaksional, kepemimpinan transformasional, kepemimpinan karismatik, kepemimpinan yang melayani, kepemimpinan terdistribusi, kepemimpinan religius, dan kepemimpinan siswa) dibandingkan dengan yang ditemukan dalam kepemimpinan pada program institusi pendidikan. Program kepemimpinan mahasiswa yang berfungsi di perguruan tinggi menyoroti pentingnya pengembangan kepemimpinan di tingkat pribadi, perguruan tinggi, dan masyarakat. Selain kepercayaan diri dan keterampilan kepemimpinan yang dimiliki pemuda, pandangan agama tentang kepemimpinan mendorong seseorang untuk "melihat-melampaui" diri mereka sendiri dan untuk melayani kebutuhan orang lain (Hine, 2013; Kusumaningrum, dkk., 2016; Hardika, dkk., 2018).

Mengacu pada rasional yang telah diuraikan, tersedianya sebuah instrumen yang dapat mengukur variabel gaya kepemimpinan mahasiswa adalah hal yang penting dalam proses pembinaan dan pengembangan kepemimpinan mahasiswa. Instrumen tersebut haruslah sahih dan ajeg mampu mengukur variabel gaya kepemimpinan mahasiswa, yang berlandaskan pada teori yang sudah kredibel dan mapan. Teori tersebut menjadi dasar dalam menyusun setiap item pernyataan yang ada dalam instrumen. Tujuan penelitian ini adalah untuk mengetahui validitas dan reliabelitas angket gaya kepemimpinan mahasiswa. Dari hasil uji tersebut akan didapatkan instrumen yang sahih dan ajeg dalam mengukur mengukur variabel gaya kepemimpinan mahasiswa.

\section{METODE}

Sesuai dengan tujuan penelitian, artikel ini menyajikan hasil validitas dan reliabelitas instrumen penelitian yang digunakan untuk mengukur variabel gaya kepemimpinan mahasiswa. Jabaran indikator yang ada dalam angket mengacu pada teori Yukl (2015), Usman (2013), dan Gunawan (2018). Ada 10 item yang dikembangkan untuk mengukur variabel gaya kepemimpinan mahasiswa. Adapun jabaran variabel gaya kepemimpinan mahasiswa ditampilkan pada Tabel 1. Angket yang digunakan untuk mengukur variabel gaya kepemimpinan mahasiswa berbentuk angket tertutup, dimana responden penelitian memilih alternatif jawaban: tidak pernah diberi skor 1; jarang diberi skor 2; sering diberi skor 3; dan selalu diberi skor 4. Mahasiswa yang menjadi responden penelitian ini adalah 35 mahasiswa UKM KSR PMI Unit Universitas Negeri Malang (merupakan organisasi kemahasiswaan / ormawa bidang kepalangmerahan yang ada di Universitas Negeri Malang).

Penelitian ini dilaksanakan dari pendanaan penelitian PNBP Fakultas Ilmu Pendidikan Universitas Negeri Malang Tahun 2019. Artikel ini merupakan bagian dari tahapan uji coba instrumen penelitian tersebut. Rumus yang digunakan untuk menguji validitas adalah dengan menggunakan rumus Korelasi Product Moment Pearson (Rumus 1). Item pernyataan yang ada dalam angket dinyatakan valid jika nilai probabilitas $(\alpha)<0,05$ (Stevens, 1996; Gunawan, 2016; Hadi, dkk., 2018; Gunawan, 2013). Sedangkan rumus yang digunakan untuk menguji reliabelitas adalah dengan menggunakan rumus Cronbach's Alpha (Rumus 2). Kriteria yang digunakan untuk menentukan reliabelitas instrumen adalah nilai ralpha $>r_{\text {tabel }}$, dan nilai $r_{\text {tabel }}$ untuk $N=35$ adalah 0,468 (Stevens, 1996; Gunawan, 2016; Hadi, dkk., 2018; Gunawan, 2013). Analisis validitas dan reliabelitas penelitian ini dengan menggunakan program IBM SPSS Statistics 24.

$$
\begin{aligned}
& \mathbf{r}=\frac{N \Sigma \mathrm{XY}-(\Sigma \mathrm{X})(\Sigma \mathrm{Y})}{\sqrt{\left(N \Sigma \mathrm{X}^{2}-(\Sigma \mathrm{X})^{2}\right)\left(N \Sigma \mathrm{Y}^{2}-(\Sigma \mathrm{Y})^{2}\right)}} \\
& \alpha=\frac{N \bar{c}}{\bar{v}+(N-1) \bar{c}}
\end{aligned}
$$


Tabel 1 Jabaran Variabel Gaya Kepemimpinan Mahasiswa

\begin{tabular}{clcc}
\hline No & \multicolumn{1}{c}{ Variabel } & Indikator & Item \\
\hline 1 & Gaya Kepemimpinan & Autokratis & 1,2 \\
& Mahasiswa (X1) & Birokratik & 3,4 \\
& & Diplomatis & 5,6 \\
& (Yukl, 2015; Usman, 2013; & Partisipatif & 7,8 \\
& Gunawan, 2018) & Free rein leader & 9,10 \\
\hline
\end{tabular}

\section{HASIL}

Hasil uji validitas variabel gaya kepemimpinan mahasiswa, yang diukur dengan dengan 10 item pernyataan, diketahui semua item valid, dengan nilai $\alpha<0,05$. Tabel 2 disajikan hasil uji validitas variabel gaya kepemimpinan mahasiswa. Berdasarkan hasil analisis validitas tersebut diketahui 10 item dinyatakan valid, sehingga semua item dalam angket tersebut dapat digunakan untuk mengukur variabel gaya kepemimpinan mahasiswa.

Tabel 2 Hasil Uji Validitas Variabel Gaya Kepemimpinan Mahasiswa

\begin{tabular}{clccc}
\hline No & \multicolumn{1}{c}{ Pernyataan } & $\begin{array}{c}\text { Pearson } \\
\text { Correlation }\end{array}$ & $\begin{array}{c}\text { Sig. } \\
\text { (2-tailed) }\end{array}$ & Keterangan \\
\hline 1 & $\begin{array}{l}\text { Pimpinan ormawa dengan kekuasaannya memberikan tugas } \\
\text { kepada para anggota organisasi }\end{array}$ & 0,372 & 0,028 & Valid \\
$2 \quad \begin{array}{l}\text { Semua anggota ormawa menyelesaikan tugas dengan baik } \\
\text { dan benar }\end{array}$ & 0,668 & 0,000 & Valid \\
$3 \quad \begin{array}{l}\text { Pimpinan ormawa memberikan tugas kepada para anggota } \\
\text { organisasi sesuai dengan prosedur yang sudah ditetapkan } \\
4\end{array}$ & 0,727 & 0,000 & Valid \\
$\begin{array}{l}\text { Pimpinan ormawa berkomunikasi dengan baik dengan para } \\
\text { anggota organisasi }\end{array}$ & 0,631 & 0,000 & Valid \\
5 & $\begin{array}{l}\text { Pimpinan ormawa memberikan semangat kepada para } \\
\text { anggota organisasi }\end{array}$ & 0,465 & 0,005 & Valid \\
\hline $\begin{array}{l}\text { Semua anggota ormawa termotivasi untuk menjalankan } \\
\text { tugasnya dengan baik }\end{array}$ & 0,732 & 0,000 & Valid \\
$\quad \begin{array}{l}\text { Pimpinan ormawa mengikutsertakan para anggota } \\
\text { organisasi dalam memberikan pendapat dan pengambilan } \\
\text { keputusan }\end{array}$ & 0,501 & 0,002 & Valid \\
$8 \begin{array}{l}\text { Saya sebagai anggota ormawa merasa pendapat saya } \\
\text { dihargai dan diapresiasi oleh organisasi }\end{array}$ & $\begin{array}{l}\text { Pimpinan ormawa memberikan kepercayaan dan kebebasan } \\
\text { kepada para anggota organisasi }\end{array}$ & 0,744 & 0,000 & Valid \\
10 & $\begin{array}{l}\text { Anggota ormawa menjalankan tugasnya dengan penuh } \\
\text { tanggung jawab }\end{array}$ & 0,717 & 0,0026 & Valid \\
\hline
\end{tabular}

Selanjutnya setelah data dianalisis dengan validitas, semua item yang valid tersebut dianalisis dengan uji reliabelitas. Tabel 3 menyajikan hasil uji reliabelitas dengan formula Cronbach's Alpha. Diketahui nilai Cronbach's Alpha sebesar 0,799. Tabel 4 disajikan hasil Cronbach's Alpha if Item Deleted. Berdasarkan hasil uji reliabelitas diketahui $\mathrm{r}_{\text {alpha }}=0,799>\mathrm{r}_{\text {tabel }}=0,468$. Dan semua Cronbach's Alpha if Item Deleted $>0,468$. Mengacu pada hasil uji reliabelitas, maka dapat disimpulkan instrumen variabel gaya kepemimpinan mahasiswa tersebut reliabel. Instrumen tersebut disimpulkan memiliki tingkat konsistensi atau keajegan yang tinggi dalam mengukur variabel gaya kepemimpinan mahasiswa. Jika mengacu pada hasil uji validitas dan reliabelitas tersebut, maka instrumen variabel gaya kepemimpinan mahasiswa yang telah dikembangkan dapat digunakan oleh peneliti lain untuk mengukur variabel gaya kepemimpinan mahasiswa. 
Tabel 3 Reliability Statistics

\begin{tabular}{cc}
\hline Cronbach's Alpha & N of Items \\
\hline .799 & 10 \\
\hline
\end{tabular}

Tabel 4 Item-Total Statistics

\begin{tabular}{lccccc}
\hline & $\begin{array}{c}\text { Scale Mean if } \\
\text { Item Deleted }\end{array}$ & $\begin{array}{c}\text { Scale Variance if } \\
\text { Item Deleted }\end{array}$ & $\begin{array}{c}\text { Corrected } \\
\text { Item-Total } \\
\text { Correlation }\end{array}$ & $\begin{array}{c}\text { Cronbach's } \\
\text { Alpha if Item } \\
\text { Deleted }\end{array}$ & Keterangan \\
\hline item1 & 30.7143 & 11.798 & .212 & .811 & Reliabel \\
item2 & 30.5143 & 10.081 & .531 & .774 & Reliabel \\
item3 & 30.3143 & 10.457 & .641 & .763 & Reliabel \\
item4 & 30.1714 & 10.676 & .512 & .776 & Reliabel \\
item5 & 29.9429 & 11.879 & .370 & .792 & Reliabel \\
item6 & 30.5143 & 9.904 & .622 & .761 & Reliabel \\
item7 & 30.2286 & 11.358 & .371 & .792 & Reliabel \\
item8 & 30.4857 & 10.375 & .662 & .760 & Reliabel \\
item9 & 30.3429 & 11.879 & .235 & .806 & Reliabel \\
item10 & 30.4571 & 9.903 & .598 & .765 & Reliabel \\
\hline
\end{tabular}

\section{PEMBAHASAN}

Mahasiswa adalah agen perubahan yang menjadi harapan kemajuan sebuah bangsa. Kepemimpinan mahasiswa perlu ditanamkan kepada diri mahasiswa secara kontinu, komprehensif, dan sistematis dalam kurikulum perguruan tinggi. Secara teoritik, pertanyaan yang masih belum bisa dijawab dengan jelas dan pasti adalah apakah "pemimpin itu dilahirkan" atau "pemimpin itu dibuat" (Betts, dkk., 2008)? Mahasiswa yang mengikuti Latihan Keterampilan Manajemen Mahasiswa (LKMM) telah membangun pendapat mereka sendiri tentang karakteristik spesifik apa yang harus dimiliki pemimpin, dan tentang siapa yang mereka anggap sebagai pemimpin (Gunawan, dkk., 2020; Zekan, dkk., 2012). Peran dan efek dari gagasan yang terbentuk sebelumnya dalam pendidikan masih merupakan bidang yang belum dieksplorasi yang menjadi perhatian praktisi dan ahli teori kepemimpinan. Jika ingin mengembangkan pemimpin yang sukses, maka membutuhkan mahasiswa untuk memahami keterampilan kepemimpinan untuk meningkatkan kemampuan mereka yang ada.

Perguruan tinggi berusaha untuk memberikan kesempatan kepada mahasiswa untuk mempraktikkan jiwa nasionalis, memberikan layanan, dan meningkatkan komunitas sebagai pemimpin masa depan. Peneliti Shertzer dan Schuh (2004) melakukan studi penelitian tentang bagaimana pemimpin mahasiswa mempersepsikan kepemimpinan dan apa yang membatasi keyakinan yang dipegang mahasiswa yang membatasi atau mempromosikan diri mereka sendiri untuk menjadi pemimpin. Para mahasiswa ditanyai berbagai pertanyaan dengan tujuan untuk menemukan persepsi tentang apa itu kepemimpinan, siapa pemimpin itu, dan apa proses kepemimpinan itu. Beberapa tema yang muncul melalui analisis wawancara, antara lain: (1) kepemimpinan adalah milik individu; (2) kepemimpinan adalah posisi; (3) pemimpin memiliki kualitas dan keterampilan tertentu; dan (4) pemimpin bertindak dari motivasi internal (Shertzer dan Schuh, 2004; Middlebrooks \& Haberkorn, 2009; Saputra, dkk., 2019).

Para peneliti menemukan keyakinan yang membatasi dan memberdayakan yang menghambat atau mendorong mahasiswa untuk mengambil peran kepemimpinan (Shertzer dan Schuh, 2004; Hogan, dkk., 1994). Keyakinan yang memberdayakan adalah keyakinan yang mendorong mahasiswa untuk mencapai peran kepemimpinan. Keyakinan tersebut dibagi menjadi tiga kategori: (1) dukungan dari orang lain; (2) peluang; dan (3) latar belakang dan lingkungan. Keyakinan yang membatasi mencegah mahasiswa dari mencapai peran kepemimpinan. Mereka berada dalam tiga kategori: (1) kurangnya kemampuan; (2) kurang percaya diri; dan (3) kurangnya kesempatan (Komives, dkk., 1998; Shertzer dan Schuh, 2004; Agustina, dkk., 2018). 
Kepemimpinan yang efektif membuat perbedaan dalam meningkatkan produktivitas organisasi. Tidak ada yang baru atau sangat kontroversial tentang gagasan itu. Bahkan setelah beberapa dekade, upaya pembaruan institusi pendidikan adalah betapa pentingnya kepemimpinan, betapa pentingnya efek tersebut dalam mendorong pembelajaran semua mahasiswa, dan apa unsur penting dari kepemimpinan yang sukses (Leithwood, dkk., 2004; Kusumaningrum, dkk., 2019). Bukti yang kuat untuk menjawab pertanyaan-pertanyaan ini, mereka yang telah berusaha menunjukkan perhatian dan investasi yang lebih besar dalam kepemimpinan sebagai jalan untuk peningkatan pendidikan skala besar harus lebih mengandalkan religius daripada fakta model kepemimpinan lainnya.

Kepemimpinan mahasiswa terletak di jantung peningkatan perguruan tinggi dan memungkinkan kaum muda untuk menyadari potensi mereka. Hal ini memiliki konsekuensi bahwa perguruan tinggi harus membangun keterampilan yang diperlukan mahasiswa, kepercayaan diri, dan motivasi bagi kaum muda untuk terlibat langsung dalam peningkatan yang lebih luas di perguruan tinggi, dan khususnya, dalam peningkatan pengalaman belajar mahasiswa. Ini memungkinkan mahasiswa menjadi pendukung untuk kebutuhan mereka sendiri dan kebutuhan orang lain. Itu terletak di jantung membangun rasa komunitas dan kepercayaan di perguruan tinggi dan membangun hubungan yang efektif (National College for School Leadership, 2006; Nurabadi, dkk., 2018; Pertiwi, dkk., 2017). Investasi dalam kepemimpinan mahasiswa adalah investasi langsung pada pemimpin masa depan dan komunitas suatu bangsa. Bagi banyak perguruan tinggi, hal ini merupakan inti dari tujuan moral mereka. Untuk memahami kepemimpinan mahasiswa, seseorang harus tahu apa yang dimaksud dengan "mengembangkan kepemimpinan" pada mahasiswa.

Perguruan tinggi perlu melakukan pendekatan, merancang program, memberikan bimbingan, dan interaksi reguler kepada mahasiswa untuk membantu menumbuhkan kepemimpinan yang efektif pada mahasiswa. Mahasiswa harus memiliki kesadaran yang lebih tinggi tentang diri mereka sendiri dan kekuatan, nilai, serta peluang mereka untuk berkontribusi dalam kehidupan (The Office of Student Leadership Development, 2013; Putri, dkk., 2019; Suminah, dkk., 2018). Perguruan tinggi tentu menginginkan mahasiswanya dapat hidup sesuai dengan nilai dan kepercayaan mereka. Untuk mencapai ini, perguruan tinggi perlu mengembangkan individu yang dapat secara efektif terlibat dengan orang lain, memanfaatkan perbedaan dan meningkatkan efektivitas kelompok yang mereka ikuti. Perguruan tinggi perlu menyulut dalam diri mahasiswa rasa urgensi dan tanggung jawab untuk menjadi agen perubahan dan warga yang terlibat. Dunia membutuhkan lebih banyak individu yang dapat secara efektif menyusun solusi kreatif yang mendukung perubahan positif, dan perguruan tinggi harus bekerja untuk mengembangkan keahlian ini pada mahasiswanya.

Dalam kepemimpinan, kecerdasan emosional sangatlah penting. Gaya kepemimpinan otoritatif tidak lagi efektif. Setelah mahasiswa melakukan transisi dari ruang kelas ke dunia nyata, mereka akan berjuang untuk posisi kepemimpinan di dunia yang berbeda. Keterampilan yang harus mereka tunjukkan adalah: (1) kesadaran diri; (2) akuntabilitas; (3) motivasi diri; dan (4) kolaborasi (Gunawan, 2018). Kesadaran diri, pemimpin harus selalu mengenali dan mengendalikan emosinya sendiri. Mereka harus memahami bagaimana tindakan mereka mempengaruhi orang-orang di sekitar mereka. Posisi kepemimpinan menuntut otoritas, tetapi juga membutuhkan kerendahan hati. Dengan menerapkan kecerdasan emosional di kelas, dosen mengajar mahasiswa untuk mengembangkan keterampilan kesadaran diri.

Akuntabilitas, ketika terjadi kesalahan, pemimpin sejati tidak menyalahkan orang lain. Mereka membuat komitmen untuk mengakui kesalahan mereka dan menghadapi konsekuensinya. Kegiatan kerja tim dan kolaborasi mengajarkan mahasiswa bagaimana merasakan tanggung jawab atas masukan yang mereka miliki pada hasil keseluruhan. Motivasi diri, adalah keterampilan emosional yang mendorong para pemimpin sukses menuju tujuan mereka. Kegiatan kecerdasan emosional di kelas akan menjadi langkah pertama untuk mengembangkan kemampuan motivasi diri yang kuat. Kolaborasi, eorang pemimpin yang sukses perlu menunjukkan keterampilan kolaborasi yang hebat. Mereka tahu kapan harus memuji orang lain dan bagaimana menyelesaikan situasi konflik dalam tim melalui komunikasi yang tepat. Ruang kelas dapat menjadi tempat mereka mengembangkan fondasi keterampilan ini. 
Pengembangan kepemimpinan dalam diri mahasiswa secara massal dianggap sebagai cara yang positif untuk meningkatkan hasil pribadi, akademik, dan kesejahteraan bagi mahasiswa dan cara lebih lanjut untuk meningkatkan manfaat sosial ekonomi (Hallinger, 2003; Leithwood, 1992; Marsh, 2012). Beberapa laporan dalam literatur yang mendokumentasikan hasil dari program pengembangan memang menunjukkan berbagai hasil positif. Pelatihan kepemimpinan mereka sendiri meningkatkan kepercayaan diri dalam menghadapi tantangan sehari-hari, dan meningkatkan keterampilan mereka, yang berpotensi memberikan efek bimbingan yang positif kepada mahasiswa (Leithwood, 1992). Program kepemimpinan inovatif bertujuan untuk menunjukkan secara empiris bahwa bimbingan dapat meningkatkan pembelajaran mahasiswa, tunduk pada evaluasi eksternal selama empat setengah tahun (Leithwood, dkk., 2003). Temuan utama adalah bahwa pendampingan mendorong keberhasilan program kepemimpinan, yang sangat bergantung pada kualitas pendampingan perguruan tinggi.

Setelah meninjau literatur tentang program yang membimbing kepemimpinan mahasiswa, Westlake (2015) mengembangkan model kerja empat poin, yang terdiri dari: praktik kepemimpinan, teori kepemimpinan, perilaku yang terkait dengan identitas, dan keterampilan abad 21. Westlake (2015) menemukan bahwa hasil umum ketika kepemimpinan mahasiswa dibimbing dapat meningkatkan: perilaku kewarganegaraan, komunikasi, kolaborasi, representasi kelompok, dan pemodelan untuk orang lain. Sebuah studi di Amerika Utara yang diikuti mengikuti 11 perguruan tinggi melalui program kepemimpinan menemukan bahwa semua peserta mencari pendidikan yang dapat mengembangkan kemampuan manajerial dan kemampuan memimpin (Steinkamp, 2016). Pemahaman yang berkembang dari praktik program penilaian diri, penerimaan diri, dan penerimaan orang lain, dapat menginspirasi penerapan berpikir kreatif pada masalah mahasiswa dalam mengembangkan dirinya (North, 2007). Program kepemimpinan petualangan berbasis luar ruangan memengaruhi perubahan pada mahasiswa (Johnson, 2012). Partisipasi dalam program seni rupa juga terbukti berkontribusi pada pengembangan kepemimpinan (Burge, 2015; Farb \& Matjasko, 2012). Brion-Meisels (2015) mengemukakan bahwa defisit dalam program kepemimpinan mahasiswa adalah tidak adanya masukan yang signifikan dari mahasiswa, dengan alasan bahwa menjadikan pandangan mahasiswa sebagai inti dari sistem pendukung akan mengembangkan hasil yang ditingkatkan.

Program kepemimpinan mahasiswa menekankan kemitraan antara mahasiswa, dosen, fakultas, universitas, dan administrator. Mahasiswa mencapai pengembangan kepemimpinan serta kepercayaan diri dan harga diri melalui pencapaian dan proses perubahan kolaboratif. Sembilan prinsip model kepemimpinan mahasiswa adalah: (1) mendongeng; (2) membuat perubahan dari dalam ke luar; (3) membuat sketsa dan mengikuti peta jalan; (4) mendorong solusi imajinatif yang tidak dicentang dan kemudian memeriksanya; (5) mengetahui sistem untuk memengaruhinya; (6) memindahkan pekerjaan dari bayangan ke tengah tahap; (7) perjelas apa yang ingin dilihat, (8) asumsikan niat terbaik dari para pemimpin dan pembuat kebijakan; dan (9) bekerja sama dengan prinsipal yang mengatur nada (Sussman, 2015; Braun \& Clarke, 2012).

Konsep menggunakan kelompok berkelanjutan dalam program kepemimpinan menyajikan kesempatan untuk membuat kelompok mikromahasiswa yang tetap bersama selama program kepemimpinan mereka (Barnett, dkk., 2000). Kelompok mendorong ikatan, kerja tim, empati, profesionalisme, dan rasa hormat, sekaligus meringankan aspek beban administratif (Georgia State University, 2015; Wituk, dkk., 2005). Baik perspektif administrator dan mahasiswa harus dipertimbangkan dalam perencanaan dan evaluasi program. Patut dicatat bahwa literatur memberikan sedikit umpan balik langsung dari mahasiswa. Memahami perspektif mahasiswa sangat penting untuk merencanakan program yang akan menarik bagi berbagai minat dan kemampuan mahasiswa.

\section{SIMPULAN}

Hasil uji validitas dan relibelitas terhadap instrumen variabel gaya kepemimpinan mahasiswa diketahui bahwa instrumen yang dikembangkan valid dan reliabel untuk mengukur variabel tersebut. Hasil penelitian ini memberikan informasi kepada praktisi seperti staf kemahasiswaan, fakultas, universitas, administrator, dan dewan pengawas tentang cara terbaik mempersiapkan pemimpin masa 
depan untuk kepemimpinan yang efektif di abad 21. Artikel ini berkontribusi pada perkembangan literatur kepemimpinan mahasiswa, dan dapat menginformasikan pimpinan perguruan tinggi yang bertanggung jawab untuk pengembangan potensi kepemimpinan mahasiswa.

\section{DAFTAR RUJUKAN}

Agustina, N. E., Sumarsono, R. B., \& Gunawan, I. 2018. Implementation of School and Community Relationship Techniques (A Case Study in SDN Karangbesuki 2 Malang, Indonesia). Proceeding 1st International Conference on Early Childhood and Primary Education (ECPE 2018), Theme: Policies and Strategies to Enhance the Quality of Early Childhood and Primary Education, Atlantis Press, 244, 145-147.

Amirianzadeh, M. 2012. Hexagon Theory-Student Leadership Development. Procedia - Social and Behavioral Sciences, 31, 333-339.

Argadinata, H., \& Gunawan, I. 2019. The Leadership of Pancasila in Education: Foundation for Strengthening Student Characters in the Industrial Revolution Era 4.0. The 4th International Conference on Education and Management (COEMA 2019), Atlantis Press.

Bafadal, I., Juharyanto, Nurabadi, A., \& Gunawan, I. 2019. Efforts to Improve the Integrity of the Principal with the Moral Debate Model. The 4th International Conference on Education and Management (COEMA 2019), Atlantis Press.

Barnett, B. G., Basom, M. R., Yerkes, D. M., \& Norris, C. J. 2000. Cohorts in Educational Leadership Programs: Benefits, Difficulties, and the Potential for Developing School Leaders. Educational Administration Quarterly, 36(2), 255-282.

Betts, S. C., Morgan, W., \& Castiglia, B. 2008. Who is a Leader? Students Implicit Theories of Leadership. Proceedings of the Academy of Organizational Culture, Communications and Conflict, 13(1), 1-18.

Braun, V., \& Clarke, V. 2012. Thematic Analysis. Dalam Cooper, H., (Ed). The APA Handbook of Research Methods in Psychology: Vol. 2. Research Designs (pp. 57-71). Washington DC: American Psychological Association.

Brion-Meisels, G. 2015. Centering Students in School-Based Support Processes: Critical Enquires and Shifting Perspectives. Teachers College Record, 117(13), 67-82.

Burge, H. B. 2015. High School students' Participation in Fine Arts Programs and Perceived Leadership SelfEfficacy. Minneapolis: Walden University.

Farb, A. F., \& Matjasko, J. L. 2012. Recent Advances in Research on School-Based Extracurricular Activities and Adolescent Development. Developmental Review, 32(1), 1-48.

Georgia State University. 2015. 4 Ways Cohort Models Benefit Graduate Students, (Online), (http://education.gsu. edu/4-ways-cohorts-models-benefit-graduate-students/), diakses 20 Maret 2020.

Gunawan, I. 2013. Statistika untuk Kependidikan Sekolah Dasar. Yogyakarta: Penerbit Ombak.

Gunawan, I. 2016. Pengantar Statistika Inferensial. Jakarat: Rajawali Pers.

Gunawan, I. 2017. Instructional Leadership Profile of Junior High School's Principal (A Case Study of Junior High School in Malang). International Research-Based Education Journal, 1(1), 64-68.

Gunawan, I. 2018. Kepemimpinan Pendidikan: Suatu Pengantar. Malang: Universitas Negeri Malang, UM Press.

Gunawan, I., Benty, D. D. N., Kusumaningrum, D. E., Sumarsono, R. B., Sari, D. N., Pratiwi, F. D. Ningsih, S. O., Putri, A. F., \& Hui, L. K. 2020. Pengaruh Gaya Kepemimpinan, Kemampuan Manajerial, Efikasi Diri, dan Prestasi Belajar terhadap Kesiapan Kerja Mahasiswa. JMSP: Jurnal Manajemen dan Supervisi Pendidikan, 4(2), 126-150.

Gunawan, I., Benty, D. D. N., Kusumaningrum, D. E., Sumarsono, R. B., Sari, D. N., Pratiwi, F. D. Ningsih, S. O., Putri, A. F., \& Hui, L. K. 2019. Validitas dan Reliabilitas Angket Keterampilan Manajerial Mahasiswa. JAMP: Jurnal Administrasi dan Manajemen Pendidikan, 2(4), 247-257.

Hadi, S., Gunawan, I., \& Dalle, J. 2018. Statistika Inferensial: Teori dan Aplikasinya. Jakarta: Rajawali Pers.

Hallinger, P. 2003. Leading Educational Change: Reflections on the Practice of Instructional and Transformational Leadership. Cambridge Journal of Education, 33(3), 329-352.

Hardika, Aisyah, E. N., \& Gunawan, I. 2018. Facilitative Learning to Improve Student Learning Creativity. Proceeding 3rd International Conference on Education Management and Administration (CoEMA 2018), Theme: The Challenges of Educational and Technology in Global and Local Era, Atlantis Press, 269, 186189.

Hine, G. S. C. 2013. Student Leadership Experiences: A Case Study. Leading and Managing, 19(1), 32-50. 
Hine, G. S. C. 2014. Student Leadership Development: A Functional Framework. Journal of Catholic Education, 18(1), 78-110.

Hogan, R., Curphy, G. J., \& Hogan, J. 1994. What we Know about Leadership: Effectiveness and Personality. American Psychologist Association, 49(6), 1-33.

Johnson, J. W. 2012. The Effect of High School Outdoor-Based Adventure Leadership Programs in Independent Schools on Personal Effectiveness and Locus of Control. Arizona: Prescott College.

Komives, S. R., Lucas, N., \& McMahon, T. R. 1998. Exploring Leadership: for College Students Who Want to Make a Difference. San Francisco: Jossey-Bass.

Kusumaningrum, D. E., Sumarsono, R. B., \& Gunawan, I. 2016. Principal Empowerment Through Soft System Methodology Approach. Proceeding International Conferences on Education and Training, 2nd ICET Theme: Improving the Quality of Education and Training Through Strengthening Networking, Fakultas Ilmu Pendidikan Universitas Negeri Malang, hlm. 205-211.

Kusumaningrum, D. E., Sumarsoso, R. B., \& Gunawan, I. 2019. Budaya Sekolah dan Etika Profesi: Pengukuran Pemberdayaan Sumber Daya Manusia Sekolah dengan Pendekatan Soft System Methodology. JAMP: Jurnal Administrasi dan Manajemen Pendidikan, 2(3), 90-97.

Leithwood, K. A. 1992. The Move Toward Transformational Leadership. Educational Leadership, 49(5), 8-12.

Leithwood, K., Louis, K. S., Anderson, S., \& Wahlstrom, K. 2004. Review of Research How Leadership Influences Student Learning. Minnesota: Center for Applied Research and Educational Improvement, University of Minnesota; Ontario Institute for Studies in Education at The University of Toronto; The Wallace Foundation.

Leithwood, K., Riedlinger, B., Bauer, S., \& Jantzi, D. 2003. Leadership Program Effects on Student Learning: The Case of the Greater New Orleans School Leadership Center. Journal of School Leadership, 13(6), 707-738.

Marsh, S. 2012. Improving Student Learning in Schools: Exploring Leadership for Learning as a Community Activity. Leading \& Managing, 18(1), 107-121.

Middlebrooks, A. E., \& Haberkorn, J. T. 2009. Implicit Leader Development: The Mentor Role as Prefatory Leadership Context. Journal Leadership Study, 2(4), 7-22.

Mozhgan, A., Parivash, J., Nadergholi, G., \& Jowkar, B. 2011. Student Leadership Competencies Development. Procedia Social and Behavioral Sciences, 15, 1616-1620.

National College for School Leadership. 2006. Student Leadership Investing in Tomorrow's Leaders for Schools and Communities. Nottingham: National College for School Leadership.

North, C. E. 2007. What do You Mean by 'Anti-Oppressive Education'? Student Interpretations of a High School Leadership Program. International Journal of Qualitative Studies in Education, 20(1), 73-97.

Nurabadi, A., Sucipto, Juharyanto, \& Gunawan, I. 2018. The Implementation of Education Management Standards in the School Laboratory State University of Malang for Improving Educational Quality. Proceeding 3rd International Conference on Education Management and Administration (CoEMA 2018), Theme: The Challenges of Educational and Technology in Global and Local Era, Atlantis Press, 269, 127-132.

Pertiwi, A. K., Cahyani, S. S. A., Diana, R. C., \& Gunawan, I. 2018. Analisis Interaksi Simbolik Kyai dan Santri dalam Perspektif Kepemimpinan Berbasis Nilai dan Etika. JMSP: Jurnal Manajemen dan Supervisi Pendidikan, 2(3), 185-191.

Pertiwi, A. K., Cahyani, S. S. A., Diana, R. C., \& Gunawan, I. 2017. Kepemimpinan Berbasis Nilai dan Etika: Suatu Kajian Interaksi Simbolik Kyai dan Santri. Prosiding Seminar Nasional Pendidikan Sinergitas Keluarga, Sekolah, dan Masyarakat dalam Penguatan Pendidikan Karakter, Fakultas Ilmu Pendidikan Universitas Negeri Malang, hlm. 1-9.

Putri, A. F., Andriningrum, H., Rofiah, S. K., \& Gunawan, I. 2019. Teacher Function in Class: A Literature Review. 5th International Conference on Education and Technology (ICET 2019), Atlantis Press.

Saputra, B. R., Adha, M. A., Ariyanti, N. S., \& Gunawan, I. 2019. Tips for Principal in Managing One Roof School (SATAP) in Underdeveloped Area. The 4th International Conference on Education and Management (COEMA 2019), Atlantis Press.

Shertzer, J. E., \& Schuh, J. H. 2004. College Student Perceptions of Leadership: Empowering and Constraining Beliefs. NASPA Journal, 42(1), 111-131.

Sobri, A. Y., Bafadal, I., Nurabadi, A., \& Gunawan, I. 2019. Validity and Reliability of Questionnaire Problematics Leadership Beginner School Principals. The 4th International Conference on Education and Management (COEMA 2019), Atlantis Press.

Steinkamp, L. A. 2016. Cultivating Post-Secondary Opportunity and Service: Youth and Young Adult Perspectives on a High School Leadership Program. Madison, Wisconsin: The University of Wisconsin. 
Stevens, J. 1996. Applied Multivariate Statistics for the Social Sciences. Mahwah: Lawrence Erlbaum Associates.

Sudharta, V. A., Mujiati, M., Rosidah, A., \& Gunawan, I. 2017. Gaya Kepemimpinan Kepala Sekolah dalam Perspektif Psikologi. JMSP: Jurnal Manajemen dan Supervisi Pendidikan, 2(2), 109-123.

Sultoni, Gunawan, I., \& Rosalinda, T. N. 2018a. Pengaruh Pembentukan Tim dan Kepemimpinan Spiritual terhadap Motivasi Diri Mahasiswa. JMSP: Jurnal Manajemen dan Supervisi Pendidikan, 2(3), 210-216.

Sultoni, Gunawan, I., \& Rosalinda, T. N. 2018b. Pengaruh Pembentukan Tim dan Kepemimpinan Spiritual terhadap Motivasi Diri Mahasiswa. JMSP: Jurnal Manajemen dan Supervisi Pendidikan, 2(3), 210-216.

Sultoni, Gunawan, I., \& Rosalinda, T. N. 2018c. Upaya Mahasiswa dalam Menyiapkan Diri Masuk ke Dunia Kerja: Suatu Kajian Deskriptif. Prosiding Seminar Nasional Pendidikan: Mendidik Cerdas Generasi Digital, Fakultas Ilmu Pendidikan Universitas Negeri Malang, hlm. 143-148.

Suminah, Gunawan, I., \& Murdiyah, S. 2018. Peningkatan Hasil Belajar dan Motivasi Belajar Siswa melalui Pendekatan Behavior Modification. Ilmu Pendidikan: Jurnal Kajian Teori dan Praktik Kependidikan, 3(2), 221-230.

Sussman, A. 2015. The Student Voice Collaborative: An Effort to Systematize Student Participation in School and District Improvement. Teachers College Record, 117(13), 119-134.

The Office of Student Leadership Development. 2013. Engaging, Exploring and Elevating Student Leadership Development at The College of William and Mary, (Online), (https://www.wm.edu/offices/ studentleadershipdevelopment/documents/StudentLeadershipDevelopmentUpdate_December2013.pdf), diakses 11 Maret 2020.

Usman, H. 2013. Manajemen: Teori, Praktik, dan Riset Pendidikan. Jakarta: PT Bumi Aksara.

Westlake, R. E. 2015. Mentoring Student Leadership: A Comparison of Two High School Programs and the Development of Student Success. Bozeman, Montana: Montana State University.

Wituk, S., Ealey, S., Clark, M. J., Heiny, P., \& Meissen, G. 2005. Community Development through Community Leadership Programs: Insights from a Statewide Community Leadership Initiative. Community Development, 36(2), 89-101.

Yukl, G. 2015. Leadership in Organizations. New York: Pearson.

Zekan, S. B., Peronja, I., \& Russo, A. 2012. Linking Theory with Practice: Students Perceptions of Leaders and Leadership Characteristics. Procedia - Social and Behavioral Sciences, 41, 237-242. 